\title{
POPULATION STRUCTURE OF ONCIDIUM POIKILOSTALIX (ORCHIDACEAE), IN COFFEE PLANTATIONS IN SOCONUSCO, CHIAPAS, MÉXICO
}

\author{
Alfredo García-González ${ }^{1,4}$, Anne Damon ${ }^{2}$, Ligia G. Esparza Olguín ${ }^{3}$ \\ \& JAVIER VALLE-MORA ${ }^{2}$ \\ ${ }^{1}$ Centro de Investigaciones y Servicios Ambientales (ECOVIDA). Carretera a Luis Lazo, km 2.5, \\ Pinar del Río, Cuba. \\ ${ }^{2}$ El Colegio de la Frontera Sur (ECOSUR). Apartado Postal 36, Carretera Antiguo Aeropuerto, km 2.5, \\ Tapachula, Chiapas, México. \\ ${ }^{3}$ El Colegio de la Frontera Sur (ECOSUR). Calle 10 X 61 No. 264, Colonia Centro, Campeche, México. \\ ${ }^{4}$ Author for correspondence: alfredmx22@gmail.com
}

AвSTRACT. We studied the population structure of Oncidium poikilostalix (Kraenzl.) M.W. Chase \& N.H. Williams (Orchidaceae) newly reported for México in 2008 in the region of Soconusco (Chiapas state) in southeast Mexico, growing in shaded coffee plantations in two rural communities, Fracción Montecristo (FM) and Benito Juárez El Plan (BJ). In 2008-2009, we determined the characteristics of these coffee plantations, and the distribution of the various life stages (seedling, juvenile, adult) on the two phorophytes: coffee bushes (Coffea arabica L.) and shade trees (Inga micheliana Harms.). Principal Component Analysis and Discrimination Analysis were used to compare all the variables evaluated. There were 1123 individuals (82.63\%) in FM and $236(17.37 \%)$ in BJ. Of those, in FM 1060 individuals (94.4\%) were epiphytic upon coffee bushes and 214 (91.06\%) in BJ, the rest were epiphytic upon the shade trees (I. micheliana). Despite displaying the characteristics of a twig epiphyte, the preferred microsites of $O$. poikilostalix were the branches of the coffee bushes, with 703 individuals (55.18\%) and the trunk of the shade trees, with 78 individuals (91.76\%). More than a third of the population was juvenile stage (37.09\%; 504 individuals). Oncidium poikilostalix probably entered México from Guatemala and appears to be a vigorous plant that is successfully adapting to its new sites of occupancy

Resumen. Se estudió la estructura poblacional de la orquídea epífita Oncidium poikilostalix (Kraenzl.) M.W. Chase \& N.H. Williams (Orchidaceae), nuevo reporte para México en 2008, en la región del Soconusco, Estado de Chiapas, al sureste del país. Crece en plantaciones de café de sombra en dos comunidades rurales, Fracción Montecristo (FM) y Benito Juárez El Plan (BJ). En 2008-2009, se determinaron las características de estas plantaciones de café, y la distribución de los distintos estadíos de vida (plántulas, juveniles, adultos) de esta orquídea, en los dos forofitos encontrados: plantas de café (Coffea arabica L.) y árboles de sombra (Inga micheliana Harms.). Se utilizó Análisis de Componentes Principales y Análisis Discriminante, para comparar todas las variables evaluadas. Hubo 1.123 individuos $(82,63 \%)$ de $O$. poikilostalix en FM y $236(17,37 \%)$ en BJ. De ellos, creciendo sobre cafetos, 1.060 individuos $(94,4 \%)$ en FM y 214 (91,06\%) en BJ, el resto ocupando árboles de sombra (I. micheliana). A pesar de mostrar las características de una epífita de ramilla, el mayor número de ejemplares de $O$. poikilostalix se contabilizó en los cafetos, en el micrositio ramas, con 703 individuos $(55,18 \%)$ y en el tronco, en los árboles de sombra, con 78 individuos (91,76\%). Más de un tercio de la población fueron individuos juveniles (504 individuos, 37,09\%). Oncidium poikilostalix probablemente entró a México desde Guatemala y parece ser una planta vigorosa, que se está adaptando con éxito a sus nuevos sitios de ocupación.

Keywords / Palabras clave: Oncidium poikilostalix, micrositio, estadíos de vida, forofito, árbol de sombra, cafeto.

Introduction. Mexico, with its diversity of ecosystems, is an orchid rich country with 1150 species currently registered (Espejo et al. 2004), expected to rise to 1300 - 1400 species (Hágsater et al. 2005). Many orchid species are confined to rather precise habitat and climatic parameters, their reproduction is notoriously slow and scarce (Ávila \& Oyama 2002; Hágsater et al. 2005), and very little is known about most species. 
The Soconusco region in the state of Chiapas, in south-east Mexico bordering with Guatemala, covers an area of $5475 \mathrm{~km}^{2}$ which includes coastal plains and part of the Sierra Madre mountain range with tropical and temperate forest ecosystems (Sánchez \& Jarquín 2004). Within that scenario a relatively high number of more than 280 orchid species have been reported for the region (Damon, 2011), including various endemic species.

An expanding human population, extending subsistence and commercial agriculture, forest fires and severe tropical storms have contributed to the destruction and fragmentation of natural forests (INEGI 1999; CNA \& CMDI 2000; Tovilla 2004), and combined with the unsustainable and illegal exploitation of orchids have led to the rapid decline of orchid numbers and biodiversity, and the near extinction of the most vulnerable species, as has happened in many other parts of the world.

In Soconusco, most of the cloud forest, which is the most orchid rich ecosystem on the planet $(60 \%$ of Mexico's orchid flora. Hágsater et al. 2005), has been transformed into coffee plantations. At first coffee was planted under the shade of original forest trees heavily populated by epiphytes, thus maintaining a high proportion of the original biodiversity (Hágsater et al. 2005). Today, many of those traditional plantations have been converted to improved varieties of coffee with monospecific shade, and some to full sun coffee. At least 213 orchid species (18.52\% of Mexican total) can be found growing within coffee plantations (Espejo et al. 2004).

Oncidium poikilostalix (Kraenzl.) M.W. Chase \& N.H. Williams was reported in 2008 as a new species for Mexico, with small populations in coffee plantations in two localities in Soconusco, Fracción Montecristo (FM) (latitude $15^{\circ} 5,31.5$ "; longitude 92 9' 57.9”) and Benito Juárez El Plan (BJ) (latitude $15^{\circ}$ 5' 15.4"; longitude $92^{\circ} 8$ ' 54.7'), both within the municipality of Cacahoatán (Solano et al. in press), having been previously reported in Guatemala and Costa Rica as Sigmatostalix costaricensis Rolfe (Behar \& Tinschert 1998) and as Sigmatostalix picta Lindl. for Nicaragua and South America (Atwood \& Mora de Retana 1999). The colonization of new areas by O. poikilostalix demonstrates the importance of the Biological Corridor Boquerón-Tacaná, which connects both nations and forms part of the Mesoamerican
Biological Corridor (CCAD-PNUD/GEF 2002).

In this study we describe the population structure of $O$. poikilostalix, comment upon its reproductive behaviour as observed in 2008-9, and analyse the relationship with the phorophytes and microsites available in two shaded coffee plantations in Soconusco, Chiapas, as an exceptional opportunity to study the characteristics of an orchid extending its distribution in these times of climate change and biodiversity loss.

\section{Materials and Methods}

Characterization of the sites - We studied the coffee plantations where $O$. poikilostalix grows to describe the density of the coffee bushes, diversity and density of the shade trees and the management regimes applied to the coffee.

Sampling unit - Having analysed the distribution of O. poikilostalix in FM and BJ we set up three plots, or sampling units, measuring $625 \mathrm{~m}^{2}(25 \times 25 \mathrm{~m}$; 0.0625 ha) in each coffee plantation, FM (plots 1 , 2 and 3) and BJ (plots 4, 5 and 6). These plots are highly representative of the populations as a whole and contained the majority of individuals of the orchid present in these sites at the time of the study.

Determination and characterization of the phorophytes, Density, Height Above Ground (HAG) and Diameter at Breast Height (DBH) - In this study, the term phorophyte is only used for coffee bushes and shade trees that had one or more individuals of O. poikilostalix growing on them at the time of the study. We determined which species were used as phorophytes by $O$. poikilostalix within the study sites, counted the numbers of individuals and determined the density of each phorophyte.

The HAG of the phorophytes (coffee bushes and shade trees) was measured with a $4 \mathrm{~m}$ straight ruler graduated with $50 \mathrm{~cm}$ intervals and the DBH was determined using a metric tape.

Microsites - Guided by the vertical zonation proposed by Johansson (1974), we developed a version specifically for the coffee bushes and shade trees in this study, to describe the different microsites, or ecological units, available for colonization by epiphytes, as follows: 


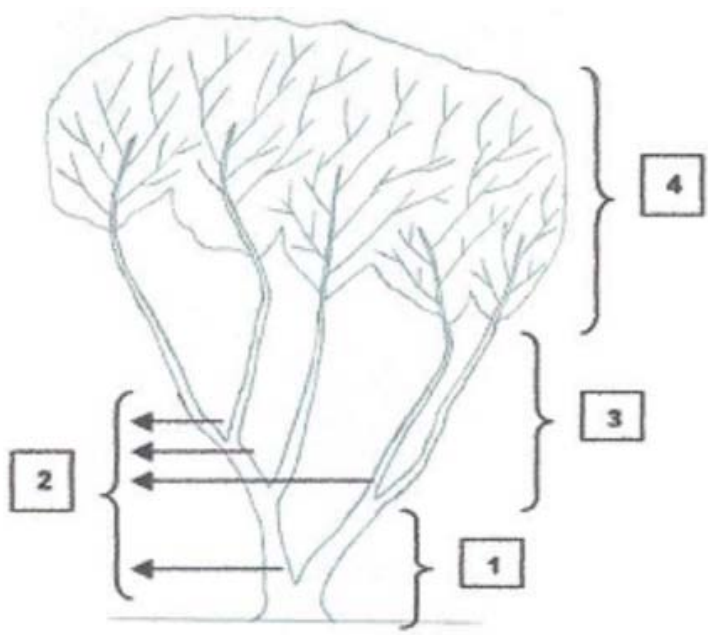

FIGURE 1. Microsites and vertical zonation of the coffee plants: 1) Trunk, 2) Fork, 3) Branches, 4) Twigs.

Microsites for coffee bushes (Fig. 1):

Zone 1 - Trunk (Tr): From the base of the bush to the first primary branches.

Zone 2 - Fork (F): Intersection between branches at various heights.

Zone 3 - Branches (B): Thick branches with diameter $>3 \mathrm{~cm}$.

Zona 4 - Twigs (Tw): Thinner, outer branches, with a diameter $<3 \mathrm{~cm}$.

Microsites for shade trees (Fig. 2):

Zone 1 - Trunk (Tr): From the base of the tree to the first primary branches.

Zone 2 - Fork (F): Intersection between branches at various heights.

Zone 3 - Branches (B): Thick branches with diameter $>3 \mathrm{~cm}$.

Due to pruning there was no zone 4 for trees. For each coffee bush and tree the length of Zone 1 and total length of Zone 3 were measured and numbers of Zone 2 were counted. It was not possible to quantify Zone 4 for the coffee bushes.

Life stages of $O$. poikilostalix - The plants of $O$. poikilostalix were classified using the following categories:

Seedling (S): Earliest stage after the protocorm in which the young plant first acquires differentiated structures $(2 \mathrm{~mm}$ to $2 \mathrm{~cm})$.

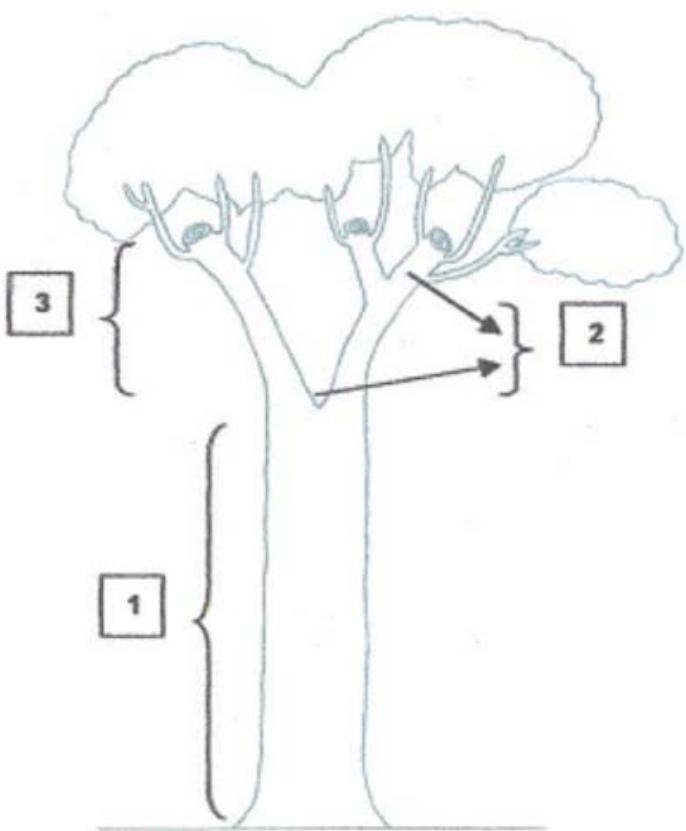

FIGURE 2. Microsites and vertical zonation of the shade trees (Inga micheliana): 1) Trunk, 2) Fork, 3) Branches.

Juvenile (J): Sexually immature but well developed plant $(>2 \mathrm{~cm})$.

Adult (A): Sexually mature plants that have flowered at least once.

Sampling - We counted all the individuals of each life stage on each of the microsites of every phorophyte within the study sites.

Statistical Analysis - We used the programmes SAS (Version 5.1.2600) and Minitab (Version 15.1.30.0) to analyse the data, which included Analysis of Variance (ANOVA), the Kruskal-Wallis test and the Goodness of Fit of Chi-squared test. Combining all the variables measured (plot, phorophyte, HAG, DBH, microsite, life stage, number of microsites available) we carried out a Principal Component Analysis and Discrimination Analysis, corroborated by Pillai's Trace test and the Mahalanobis test, to derive the population structure and preferences of the orchid $O$. poikilostalix.

\section{Results}

Characterization of the sites - The coffee plantations FM and BJ consist of arabica coffee bushes (Coffea arabica L. Rubiaceae) and monospecific shade trees 
TABLE 1. Colonization of phorophytes, coffee, and shade trees (Inga micheliana) per year of study, in Fracción Montecristo (FM) and Benito Juárez (BJ).

\section{8}

\begin{tabular}{lcc}
\hline & FM & BJ \\
Coffee bushes & 109 & 37 \\
Shade trees & 6 & 2 \\
Total phorophytes & 115 & 39 \\
General \% ocupation & 23.27 & 8.72 \\
& 2009 & \\
\hline & FM & BJ \\
Coffee bushes & 108 & 37 \\
Shade trees & 6 & 0 \\
Total phorophytes & 114 & 37 \\
General \% ocupation & 23.07 & 8.25 \\
\hline
\end{tabular}

("Chalum"; Inga micheliana Harms.: Mimosaceae) as well as occasional species of native, fruit or timber trees which also serve to shade the coffee bushes, such as Cedrela mexicana Roem. (Meliaceae), Citrus sp. (Rutaceae) and Nectandra sp. (Lauraceae) in FM and Inga lauriana (Sw.) Willd. (Fabaceae), Citrus sp., Trema micrantha (L.) Blume (Ulmaceae) and Vernonia deppeana Less. (Asteraceae), in BJ. Both plantations can be considered as simple polycultures (sensu Williams-Linera \& López-Gómez, 2008, for coffee plantations in the Mexican state of Veracruz). The plantations of FM and BJ are approximately 15 and 20 years old and are situated at an average altitude of $1410 \mathrm{~m}$ and $1440 \mathrm{~m}$, respectively.

In both FM and BJ no agrochemicals are applied, and management is limited to manually eliminating weeds with a machete twice a year, and the pruning of shade trees and coffee bushes once a year. Most importantly, unlike in most plantations in the region, these farmers do not eliminate the moss, and with it the epiphytes, that grow on the branches and trunks of the coffee bushes.

Determination of the phorophytes - Most of the trees were I. micheliana and this was the only tree species that acted as a phorophyte. The coffee bushes themselves were also phorophytes.

As shown in Table 1, not all the coffee bushes and shade trees were colonized by $O$. poikilostalix. The Chi-squared test showed a significant difference between the colonization of the two phorophytes, with an apparent preference for coffee bushes in $2008\left(\mathbf{X}^{2}=123.662 ;\right.$ d.f. $\left.=1 ; \mathrm{P}=9.98887 \mathrm{e}-29\right)$, which was maintained in $2009\left(\mathbf{X}^{2}=127.954\right.$; d.f. $=1 ; \mathrm{P}=$ 1.14875e-29). In 2009, 23 O. poikilostalix were lost due to maintenance activities, thus reducing also the number of trees determined as phorophytes. "Chalum" (I. micheliana) was the only tree species to act as a phorophyte (58 individuals, $79.45 \%$ of all trees. 27 FM; $31 \mathrm{BJ}$ ) and population sizes of $O$. poikilostalix were notably different between sites and phorophytes (Table 7).

Density of coffee bushes and shade trees - Within the experimental plots, in FM there were 459 coffee bushes and 35 shade trees, whereas in BJ there were 410 coffee bushes and 38 shade trees. The density of coffee bushes was 2448 and 2187 coffee bushes/ha in FM and BJ, respectively, whereas shade tree density was more variable, at 187 and 203 trees/ha for FM and $\mathrm{BJ}$, respectively.

Height Above Ground (HAG) and Diameter at Breast Height (DBH )of the phorophytes - There were significant differences between the heights of the coffee bushes in the three plots of $\mathrm{FM}(\mathrm{Fc}=5.51$; d.f. $=$ $5 ; \mathrm{P}=5.3 \mathrm{e}-05)$, but not for the shade trees $(\mathrm{Fc}=1.21$; d.f. $=5 ; \mathrm{P}=0.315)($ Table 2). For DBH (Table 2), the Kruskal-Wallis test showed significant differences between coffee bushes $\left(\chi^{2}=13.73\right.$; d.f. $\left.=5 ; \mathrm{P}=0.017\right)$, but not for shade trees $(\mathrm{Fc}=2.04$; d.f. $=5 ; \mathrm{P}=0.084)$, evaluating with ANOVA. Some coffee bushes were not included due to measuring less than $1.30 \mathrm{~m}$ in height.

TABle 2. Height Above Ground (HAG) (m) and Diameter at Breast Height $(\mathrm{DBH})(\mathrm{cm})$ averages for the phorophytes, coffee bushes and shade trees, in Fracción Montecristo (FM) and Benito Juárez $(\mathrm{BJ})$.

\begin{tabular}{lcccc}
\hline & \multicolumn{2}{c}{ Coffee } & \multicolumn{2}{c}{ Trees } \\
& FM & BJ & FM & BJ \\
\hline Average HAG & 3.93 & 3.03 & 6.08 & 6.23 \\
Average DBH & 9.58 & 9.37 & 76.08 & 62.84 \\
\hline
\end{tabular}


TABLE 3. General average dimensions $(\mathrm{m})$ of the trunk microsites (Zone 1) and branches (Zone 3 ) and average number of forks (Zone 2) for the phorophytes, coffee bushes and shade trees, in Fracción Montecristo (FM) and Benito Juárez (BJ).

\begin{tabular}{lcccc} 
& \multicolumn{2}{c}{ Coffee } & \multicolumn{2}{c}{ Trees } \\
& FM & BJ & FM & BJ \\
\hline Trunk (Zone 1) & 1.53 & 1.17 & 3.39 & 2.96 \\
& & & & \\
Branches (Zone 3) & 2.15 & 1.62 & 2.7 & 3.24 \\
Fork (Zone 2) & 1.25 & 1.5 & 1.11 & 0.97 \\
\hline
\end{tabular}

Availability of Microsites - As was expected, the total length of the branches (Zone 2) of the coffee bushes and the length of the trunks (Zone 1) of the trees were greater than the other microsites of these phorophytes (Table 3). The forks between branches could be found at different heights above the ground.

Number of orchids per microsite - The majority of individuals of $O$. poikilostalix occupied Zone 3, the branches, in the case of the coffee bushes (703 individuals) and Zone 1, the trunk, of the shade trees (78 individuals). Plot 1 (FM) had the greatest population (762 individuals), with the highest numbers of individuals in each microsite [Zone 1, 148; Zone 2 (coffee bushes only), 2; Zone 3, 383; Zone 4 (coffee bushes only) 229] and there was a significant difference between Plot 1 as compared to Plots 2 and 3 $\left(\mathbf{X}^{2}=44.23\right.$; d.f. $\left.=2 ; \mathrm{P}=2.48644 \mathrm{e}-10\right)$ (Fig. 3). For BJ, the number of orchid individuals on the coffee plants differed significantly between all three plots $\left(X^{2}=7.43\right.$; d.f. $=2 ; \mathrm{P}=0.024$ ) (Fig. 4).

Shade trees were less favoured as phorophytes than coffee bushes, and no orchids were found growing in Zone 2, the forks of the trees. However, one specimen of I. micheliana had 52 individuals, 46 on Zone 1, and 6 on Zone 3.

Principal Component Analysis - Comparing all the variables for both types of phorophyte (plot, height above ground, DBH, number of orchid individuals on each microsite, number available of each microsite) we determined whether there were differences between the experimental plots.

For coffee bushes in FM, there was a significant
Pillai's Trace: $P=0.0002 ; F=2.70$

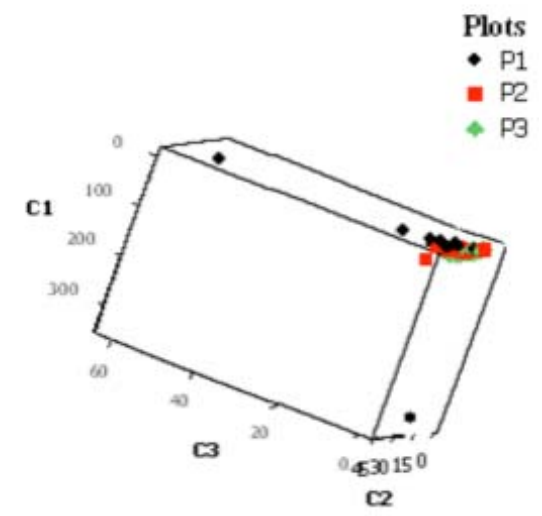

Figure 3. Scatter Plot produced by Principal Component Analysis, for coffee bushes in Fracción Montecristo (FM). Variables included: Height Above Ground (HAG), Diameter at Breast Height (DBH), number of orchid individuals on each microsite, number available of each microsite.

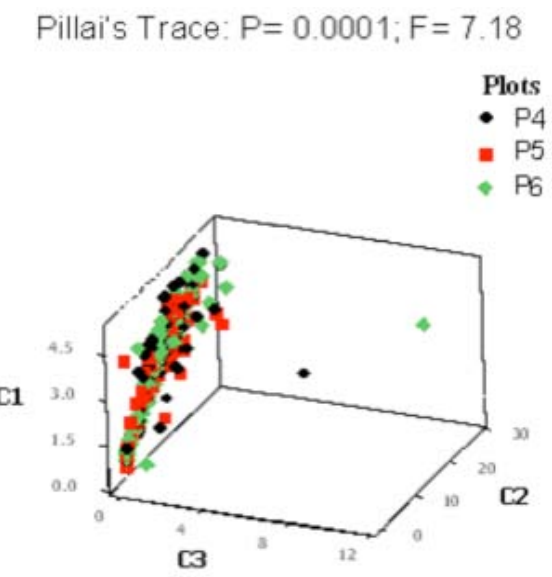

FIgURE 4. Scatter Plot produced by Principal Component Analysis, for coffee bushes in Benito Juárez El Plan (BJ). Variables included: Height Above Ground(HAG), Diameter at Breast Height (DBH), number of orchid individuals on each microsite, number available of each microsite.

difference between Plot 1 and Plots 2 and 3, (Table 3) corroborated by the Mahalanobis test (Table 4). In BJ, there were significant differences between all the plots (Fig. 4), confirmed by the Mahalanobis test (Table 5).

In the case of the shade trees in FM, Plot 2 was significantly different to Plots 1 and 3 (Fig. 5) corroborated by the Mahalanobis test (Table 6). In BJ, the apparent significant difference between Plot 3 
TABle 4. Mahalanobis test in Discriminant Analysis for shade tree phorophytes in Fracción Montecristo.

\begin{tabular}{lccc}
$\begin{array}{l}\text { Prob }>\text { Mahalanobis Distance for Squared Distance to Plot } \\
\text { Plot }\end{array}$ & P1 & P2 & P3 \\
\hline P1 & 1.0000 & 0.0003 & $<.0001$ \\
P2 & 0.0003 & 1.0000 & 0.7010 \\
P3 & $<.0001$ & 0.7010 & 1.0000 \\
\hline
\end{tabular}

Table 5. Mahalanobis test in Discriminant Analysis for coffee plant phorophytes in Benito Juárez.

\begin{tabular}{cccc}
\multicolumn{4}{c}{ Prob $>$ Mahalanobis Distance for Squared } \\
Plot & P4 & P5 & P6 \\
\hline P4 & 1.0000 & $<.0001$ & 0.0003 \\
P5 & $<.0001$ & 1.0000 & $<.0001$ \\
P6 & 0.0003 & $<.0001$ & 1.0000 \\
\hline
\end{tabular}

and Plots 1 and 2 was shown to be non-existent by the application of Pillai's Trace test (Fig. 6).

Number of individuals of life stages - For the shade trees, in FM, the distribution of the three life stages was: $\mathrm{S}$ - 35, J - 7, A - 21. In BJ there were no seedlings observed on the shade trees, J - 10, A - 12. For coffee bushes in FM: S - 344, J - 399, A - 317; BJ: S - 63, J 88 , A - 63. The majority of individuals of all life stages were found growing on Zone 3 (703 individuals) and

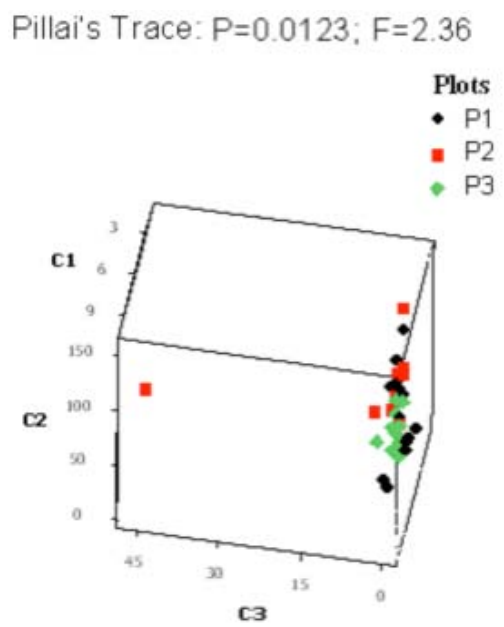

Figure 5. Scatter Plot produced by Principal Component Analysis, for shade trees in Fracción Montecristo (FM). Variables included: Height Above Ground (HAG), Diameter at Breast Height (DBH), number of orchid individuals on each microsite, number available of each microsite.
TABLE 6. Mahalanobis test in Discriminant Analysis for shade tree phorophytes, Fracción Montecristo.

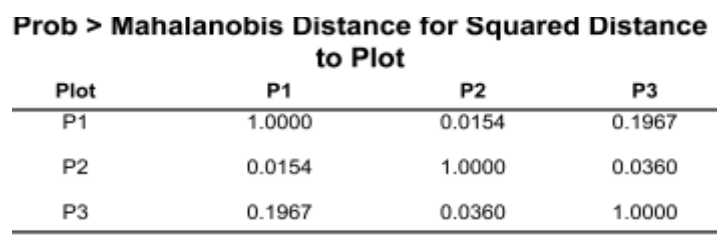

very few were found on Zone 2 (4). Plot 1 had the most individuals and the greatest number of all life stages growing on all the microsites.

\section{Discussion}

Height, DBH y density of present and potential phorophytes. Its influence on the ecosystem - The density and architecture of present and potential phorophytes, linked to the HAG and DBH of the trees and coffee bushes, create variations in the conditions of temperature and humidity which in turn affect the germination and establishment of epiphytes (Benzing 1990). In the case of the forks between branches, the levels of humidity and amount of humus accumulated, which are favourable for the establishment of many epiphytes, depend upon the size and position of the fork in relation to sources of organic matter and moisture. The combination of these aspects can have a substantial effect upon the penetration of light, air

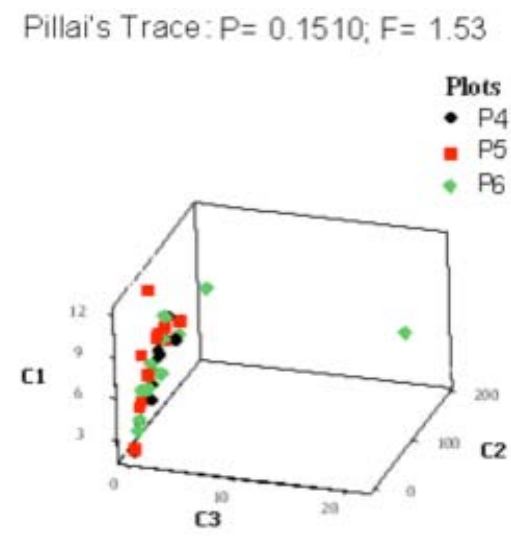

Figure 6. Scatter Plot of Principal Component Analysis, for shade trees in Benito Juárez El Plan (BJ). Variables included: Height Above Ground (HAG), Diameter at Breast Height $(\mathrm{DBH})$, number of orchid individuals on each microsite, number available of each microsite. 
TABLE 7. Oncidium poikilostalix: number of individuals per microsite, life stage and type of phorophyte in 2008, for Fracción Montecristo (FM) and Benito Juárez (BJ).

\begin{tabular}{lccccccccc}
\multicolumn{1}{c}{ Coffee } & \multicolumn{7}{c}{ Trees } \\
\hline $\begin{array}{c}\text { FM } \\
\text { No. } \\
\text { individuals }\end{array}$ & Zone 1 & Zone 2 & Zone 3 & Zone 4 & Total & Zone 1 & Zone 2 & Zone 3 & Total \\
Seedlings & 78 & 1 & 146 & 119 & $\mathbf{3 4 4}$ & 35 & 0 & 0 & $\mathbf{3 5}$ \\
Juvenile & 52 & 1 & 225 & 121 & $\mathbf{3 9 9}$ & 5 & 0 & 2 & $\mathbf{7}$ \\
Adults & 42 & 0 & 218 & 57 & $\mathbf{3 1 7}$ & 16 & 0 & 5 & $\mathbf{2 1}$ \\
$\quad$ Total & $\mathbf{1 7 2}$ & $\mathbf{2}$ & $\mathbf{5 8 9}$ & $\mathbf{2 9 7}$ & $\mathbf{1 0 6 0}$ & $\mathbf{5 6}$ & $\mathbf{0}$ & $\mathbf{7}$ & $\mathbf{6 3}$ \\
\hline BJ & & & & & & & & & \\
Seedlings & 14 & 0 & 23 & 26 & $\mathbf{6 3}$ & 0 & 0 & 0 & $\mathbf{0}$ \\
Juvenile & 11 & 1 & 49 & 27 & $\mathbf{8 8}$ & 10 & 0 & 0 & $\mathbf{1 0}$ \\
Adults & 13 & 1 & 42 & 7 & $\mathbf{6 3}$ & 12 & 0 & 0 & $\mathbf{1 2}$ \\
$\quad$ Total & $\mathbf{3 8}$ & $\mathbf{2}$ & $\mathbf{1 1 4}$ & $\mathbf{6 0}$ & $\mathbf{2 1 4}$ & $\mathbf{2 2}$ & $\mathbf{0}$ & $\mathbf{0}$ & $\mathbf{2 2}$ \\
\hline
\end{tabular}

circulation and the surface available for establishment of epiphytes. Those same variables will also affect the abundance and diversity of bacteria and mycorrhizal fungi, the availability of pollinators and the abundance of herbivores and their natural enemies.

The density of coffee bushes was 2448 and 2187 coffee bushes/ha in FM and BJ, respectively, which compares to a density of approximately 2000 bushes/ ha in traditional coffee plantations in Colombia, contrasting with intensive plantations in that country which may have up to 10,000 bushes/ha of dwarf, high yielding varieties (Gallego 2005). Shade tree density was more variable, at 187 and 203 trees/ha for FM and BJ, respectively. These densities are similar to the density of shade trees in coffee plantations in Veracruz, which range from 193 - 220 trees/ha, but which are taller than the trees in our study, possibly due to less aggressive pruning. However, the density of trees in the original cloud forest is approximately 638 trees/ha, with a maximum height of approximately $22 \mathrm{~m}$ (WilliamsLinera \& López-Gómez 2008), and O. poikilostalix may be better adapted to the environmental conditions, and for attracting pollinators and dispersing seeds within this denser vegetation of the original cloud forest.

Number of orchids per type of phorophyte and per microsite - Vascular epiphytes tend to display patterns of vertical distribution on their phorophytes that reflect their range of tolerance for light and humidity and other ecophysiological adaptions (Johansson 1974; Krömer et al. 2007). A study carried out in humid tropical forests in Alto Orinoco in Venezuela suggests that forks represent an extremely important microsite for many epiphytic species of plants, whereas other species clearly favour vertical substrates (HernándezRosas 2000). In forks, retention of both humidity and organic matter are greater than for vertical substrates, as water drains away very quickly on vertical substrates, carrying with it organic matter and dissolved nutrients.

In this study, the percentage colonization of both phorophytes was similar, $13.79 \%$ of shade trees and $16.8 \%$ of coffee bushes, and the higher numbers of $O$. poikilostalix on coffee bushes could simply be due to the presence of more than 10 times more coffee bushes (869) than shade trees (73) in the experimental plots.

Oncidium poikilostalix has a relatively high pollination rate and each capsule contains thousands of seeds (García-González 2009, unpublished data) which are carried by multidirectional breeze and thermal currents, the similarity of the percent colonization, despite the great difference in the quantities of potential phorophytes in the experimental plots, suggest that only this small, and constant fraction of phorophyte populations have the necessary microorganisms and /or environmental conditions to permit the establishment of colonies of O. poikilostalix and that it is a minority case. 
From a numerical point of view 1273 out of a total of $1358(93.74 \%)$ individuals of $O$. poikilostalix were found growing on coffee bushes indicating that they offer adequate conditions for germination and development, and conditions that are probably similar to the original substrate preferences of this orchid. This is interesting as Coffea arabica is an introduced species, with just over one century in the Soconusco region (Baxter 1997; ICO 2009) and has effectively creating a new habitat or opportunity. In tropical forests the canopy is closed, there is little vegetation on the forest floor and even twig epiphytes growing on the outer extremes of the branches are not exposed to full sun or extreme dryness. In coffee plantations the canopy is more open, shade trees are widely spaced and light penetrates down to the coffee bushes. We have no information concerning the type of phorophytes and microsites colonized by $O$. poikilostalix in natural habitats, but obviously the branches of coffee bushes, followed by the trunks of coffee bushes and shade trees are the conditions that most clearly fulfil the requirements and mimic the natural habit of $O$. poikilostalix. In the case of shade trees, the trunk is maybe too thick, too dark, and maybe even too constantly damp, whereas the pruned branches are maybe too exposed in this more open type of vegetation cover. The trees are regularly pruned, to increase the light reaching the coffee plants, and the profusion of thinner branches is eliminated and with it any orchids attached to them.

The long fibrous roots capable of wrapping round thin branches and the size of $O$. poikilostalix indicate twig epifitism but in this study this species was shown to prefer thicker branches and to be able to establish on trunks, but this may be an artefact of management practices carried out within coffee plantations wherein thinner branch growth is annually pruned out, both in shade trees and coffee bushes. The branches represent an intermediate microsite, in terms of light intensity, air currents, bark texture, available surface area, thickness, and in the absence of stable twig microsites, may offer the next best option and fall within the natural range of tolerance of this orchid. Twig epiphytes tend to mature relatively rapidly but have shorter lifecycles than most orchid species that may be a reflection of their risky and ephemeral habitat (Gravendeel et al. 2004; Hágsater et al. 2005; Mondragón et al. 2007). Various species of small twig epiphytes colonize the thinnest branches of coffee bushes in Soconusco region, especially Erycina crista galli (Rchb.f.) N.H.Williams \& M.W.Chase, Leochilus labiatus (Sw.) Kuntze, L. oncidioides Knowles \& Westc., L. scriptus (Sw.) Rchb.f., Notylia barkeri Lindl., and Ornithocephalus tripterus Schltr. (Damon 2009, unpublished data), and all are even smaller than $O$. pokilostalix, which may explain why this orchid appears to fall outside of the twig epiphyte category.

\section{Differences between Plots and number of individuals} of life stages - We found significant differences between the coffee bushes and the shade trees, affecting all the variables monitored, but mainly due to the great difference in the number of plants of each category. All life stages of $O$. poikilostalix were found on the trunk of the shade trees (Table 7). In FM, with the largest and most established population of O. poikilostalix, our data for the number of seedlings and numbers of adult plants indicate low survival rates on Zone 1, the trunk (Table 7). The trunks of the trees will receive orchid seeds falling from above and the high humidity possible favours the presence of mycorrhizal fungi which facilitate the germination of the seeds. However, later on, development of the young plant may be hindered by low light levels, reduced air circulation and, during the rainy season, humidity may reach intolerable levels complicated by mud splashed from the ground. In BJ the behaviour of the orchid appeared to be different, with far greater levels of survival on the trunks, but the population is still too small to draw conclusions.

On the branch microsite, in both FM and BJ, where a greater number of individuals were found from all three life stages, recruitment of seedlings was relatively lower, although survival rates were higher in most of the Plots (Table 7). After Zone 3, the next most occupied microsite was the twigs, Zone 4 (Table 7), although in Plots 3 and 5 no individual were observed on this microsite. Plot 3 had a slightly greater density of coffee bushes implying less light reaching the coffee twigs, but Plot 5 was no different, making it difficult to explain this difference. The 
relative abundance on this microsite agrees with the size and physical characteristics of $O$. poikilostalix, but levels of survival were not high, as few adult plants were observed in comparison with the numbers of seedlings and juveniles, although this could simply be due to the rough handling and breakage of twigs during the harvest, and partial removal of twigs during annual pruning.

In the case of shade trees the low numbers of individuals of $O$. poikilostalix (Table 7) prevented an adequate analysis of the distribution of individuals of the three life stages.

Oncidium poikilostalix is an orchid that appears to be well adapted to the conditions in the coffee agroecosytems of southeast Mexico, colonizing most of the available microsites on both shade trees and coffee bushes, although we have no means of comparing our data with populations inhabiting the original, natural habitat of this plant. Despite our observation that a small proportion of individuals of $O$. poikilostalix were lost due to management practices in 2009, the majority of the coffee plantations in Soconusco region are administered by small producers, which for cultural and economic reasons carry out the bare minimum of maintenance procedures, which favours stability and the persistence of epiphytes. Under these conditions, $O$. poikilostalix is slowly expanding its distribution and may threaten the smaller populations of the similar Sigmatostalix guatemalensis (awaiting verification of its new name within Oncidium. Rodolfo Solano-Gómez, personal communication), which is a protected plant in Mexico and established in small numbers within the coffee plantations FM and BJ.

AcKNOWLEDGEMENTS. This study formed part of the Project: "Diversity and conservation of the orchids of the Biological Corridor Tacana-Boqueron", and we are grateful to the National Council for Science and Technology (CONACYT-FONDOS MIXTOS-CHIAPAS, CHIS-2006206-45802) for funding. We thank the coffee producers of the communities Fracción Montecristo and Benito Juárez El Plan, for permitting us access to their plantations to carry out the field work for this study.

\section{LiTERATURE CITED}

Atwood, J.T. \& D.E. Mora de Retana. 1999. Family \# 39 Orchidaceae: Tribe Maxillarieae: subtribes Maxillariinae and Oncidiinae. Fieldiana, Bot. 40 (1-4): $1-82$.

Ávila, I. \& K. Oyama. 2002. Manejo sustentable de Laelia speciosa (Orchidaceae). Biodiversitas (Boletín Bimestral de la Comisión Nacional para el Conocimiento y Uso de la Biodiversidad) 7 (43): 9-12.

Baxter, J. 1997. El libro del café. Susaeta Ediciones, Madrid.

Behar, M. \& O. Tinschert. 1998. Guatemala y sus orquídeas. Bancafé, Guatemala.

Benzing, D.H. 1990. Vascular Epiphytes. Cambridge University Press, New York.

CCAD-PNUD/GEF. 2002. El Corredor Biológico Mesoamericano, México. Proyecto Para la Consolidación del Corredor Biológico Mesoamericano. Serie Técnica 05. [Internet page] [cited on 20 december 2009]. Available at URL: http:www.ccad.ws/pccbm/ docs/cbmmexico.pdf

CNA \& CMDI (Comisión Nacional del Agua y Centro para la Migración y el Desarrollo Internacional). 2000. Plan de conservación de suelos y agua para la costa de Chiapas, México.

Damon, A. 2011. Diversidad y conservación de las orquídeas del corredor biológico Tacaná-Boquerón. Final report of project. FONDOS MIXTOS-CHIAPAS: CHIS-2006-C06-45802. 2007-2010.

Espejo, A., A.R. López-Ferrari; R. Jiménez \& L. Sánchez. 2004. Las orquídeas de los cafetales en México: una opción para el uso sostenible de ecosistemas tropicales. Rev. Biol. Trop. 53 (1-2): 73-84.

Gallego, M.C. 2005. Intensidad de manejo del agroecositema del café (Coffea arabica L.) (monocultivo y policultivo) y riqueza de especies de hormigas generalistas. Boletín del Museo de Entomología de la Universidad del Valle 6 (2): 16-29.

Gravendeel, B., A. Smithson, F.J.W. Slik \& A. Schuiteman. 2004. Epiphytism and pollinator specialization: drivers for orchid diversity?. Phil. Trans. R. Soc. Lond. B. 359: 1523-1535.

Hágsater, E.; M. Soto; G. Salazar; R. Jiménez; M. López \& R. Dressler. 2005. Las Orquídeas de México. Productos Farmacéuticos, S.A. of C.V, México.

Hernández-Rosas, J.I. 2000. Patrones de distribución de las epífitas vasculares y arquitectura de los forofitos de un bosque húmedo tropical del Alto Orinoco, Estado de Amazonas, Venezuela. Acta Biológica Venezuelica 20 (3): 43-60.

ICO (International Coffee Organization). 2009. Historical data. [Internet page] [cited on 22 october 2009]. Available at URL: http:www.ico.org/historical.asp 
INEGI (Instituto Nacional de Estadística, Geografía e Informática). 1999. El crecimiento de la población y sus repercusiones sobre el medio ambiente de México. Anuario Estadístico, México.

Johansson, D. 1974. Ecology of vascular epiphytes in West African Rain Forest. Acta Phytogeogr. Suecica 59:1-129.

Krömer, T.; M. Kessler \& S.R. Gradstein. 2007. Vertical stratification of vascular epiphytes in submontane and montane forest of the Bolivian Andes: the importance of the understory. Plant Ecol. 189: 261-278.

Mondragón, D.; C. Maldonado \& R. Aguilar-Santelises. 2007. Life history and demography of a twig epiphyte: a case study of Erycina crista-galli (Orchidaceae). Selbyana 28 (2): 137-144.

Sánchez, J.E. \& R. Jarquín (ed.). 2004. La Frontera Sur. Reflexiones sobre el Soconusco, Chiapas, y sus problemas ambientales, poblacionales y productivos.
CD. ECOSUR.

Solano, R., Jiménez-Machorro, R. \& Damon, A. (in press). Two new records and one rediscovery for Orchidaceae of Mexico. Acta Botánica Mexicana.

Tovilla, C. 2004. La dimensión de la crisis ambiental en la costa de Chiapas y la necesidad de un programa de ordenamiento de las actividades. In: Sánchez, J.E. \& R. Jarquín (ed.). 2004. La Frontera Sur. Reflexiones sobre el Soconusco, Chiapas, y sus problemas ambientales, poblacionales y productivos. CD. ECOSUR.

Williams-Linera, G. \& A. López-Gómez. 2008. Estructura y diversidad de la vegetación leñosa. In: Manson, R.H.; V. Hernández-Ortiz; S. Gallina \& K. Mehltreter (ed.). 2008. Agroecosistemas cafetaleros de Veracruz: biodiversidad, manejo y conservación. Instituto de Ecología A.C. (INECOL) e Instituto Nacional de Ecología (INE-SEMARNAT), México, pp. 55-68. 